\title{
BMI open Oestrogen receptor polymorphisms are an associated risk factor for mild cognitive impairment and Alzheimer disease in women APOE $\varepsilon 4$ carriers: a case-control study
}

\author{
Manuel Fernández-Martínez, ${ }^{1}$ Xabier Elcoroaristizabal Martín, ${ }^{2}$ \\ Elisa Blanco Martín, ${ }^{1}$ Luis Galdos Alcelay, ${ }^{3}$ Iratxe Ugarriza Serrano, ${ }^{1}$ \\ Fernando Gómez Busto, ${ }^{4}$ Maite Álvarez-Álvarez, ${ }^{2}$ Ana Molano Salazar, ${ }^{1}$ \\ Rocio Bereincua Gandarias, ${ }^{1}$ Sandra Inglés Borda, ${ }^{3}$ Juan María Uterga Valiente, ${ }^{5}$ \\ Begoña Indakoetxea Juanbeltz, ${ }^{6}$ María Ángeles Gómez Beldarraín, ${ }^{7}$ \\ Josefa Moraza López, ${ }^{8}$ Myriam Barandiarán Amillano, ${ }^{6}$ Marian M de Pancorbo ${ }^{2}$
}

To cite: FernándezMartínez M, Elcoroaristizabal Martín X, Blanco Martín E, et al. Oestrogen receptor polymorphisms are an associated risk factor for mild cognitive impairment and Alzheimer disease in women APOE $\varepsilon 4$ carriers: a casecontrol study. BMJ Open 2013;3:e003200. doi:10.1136/bmjopen-2013003200

- Prepublication history and additional material for this paper is available online. To view these files please visit the journal online (http://dx.doi.org/10.1136/ bmjopen-2013-003200).

MF-M and XEM contributed equally.

Received 16 May 2013 Revised 30 July 2013 Accepted 6 August 2013

For numbered affiliations see end of article.

Correspondence to Dr Manuel Fernández Martínez; mfernandezm@ oroitu.com

\section{ABSTRACT}

Objectives: Examine the role of single nucleotide polymorphisms (SNPs) in the oestrogen receptor (ER) genes: rs9340799, rs2234693, rs2228480 (in the ESR1 gene) and rs4986938 (in the ESR2 gene) as a risk factor for amnesic mild cognitive impairment (MCla) and Alzheimer's disease (AD) and its possible association with the apolipoprotein $\mathrm{E}(A P O E)$ gene. Design: We have investigated the independent and combined association of different alleles of the oestrogen receptor genes and $\mathrm{APOE}^{*} \varepsilon 4$ allele with cognitive impairment using a case-control design.

Setting: Participants were prospectively recruited from the neurology departments of several Basque Country hospitals.

Participants: This study comprised 816 Caucasian participants who were aged 50 years and older: 204 MCla, 350 sporadic patients with AD and 262 healthy controls.

\section{Primary and secondary outcome measures:}

Clinical criteria and neuropsychological tests were used to establish the diagnostic groups ( $\mathrm{MCla}, \mathrm{AD}$ and healthy controls). A dichotomous variable was used for each allele and genotype and the association with $\mathrm{MCla}$ and $A D$ was established using Logistic Regression Models.

Results: Neither alleles nor genotypes of SNPS rs 9340799 , rs2234693, rs2228480 and rs4986938 of oestrogen receptor genes (ESR1 and ESR2) are independently associated with the risk of MCla or $\mathrm{AD}$. However, the genetic profile created with the combination of the less represented alleles of these SNPs (expressed as XPAA) was associated with an increased risk for MCla (OR=3.30, 95\% $\mathrm{Cl} 1.28$ to $8.54, \mathrm{p}=0.014$ ) and $\mathrm{AD}$ $(\mathrm{OR}=5.16,95 \% \mathrm{Cl} 2.19$ to $12.14, \mathrm{p}<0.001)$ in women $\mathrm{APOE}^{\star} \varepsilon 4$ allele carriers.

Conclusions: The less represented alleles of SNPS studied are associated with MCla and $A D$ in $A P O E^{\star} E 4$

\section{ARTICLE SUMMARY}

Strengths and limitations of this study

- It was one of the first studies to investigate the association between polymorphisms of the ER genes and cognitive function not only in patients with $A D$, but also in patients with MCla.

- It is a multicenter study with a patient sample that allows gender stratification.

- The study population comes from the hospital setting. A community-based study could provide more information.

- The levels of estradiol and the previous oestrogen replacement therapy were unknown.

carriers. In particular, the genetic profile created with the less represented alleles of ESR1 and ESR2 SNPs are associated with an increased risk for MCla and $A D$ in women $\mathrm{APOE} \varepsilon 4$ allele carriers.

\section{INTRODUCTION}

Alzheimer's disease $(\mathrm{AD})$ is the most common form of dementia, currently affecting over 9 million Americans and Europeans; its aetiology is complex and multifactorial. Several genes associated with sporadic and familial $\mathrm{AD}$ have been identified, but it is estimated that probably more than $50 \%$ of genetic risk remains unidentified. ${ }^{1}$

The apolipoprotein $\mathrm{E}$ gene $(A P O E)$ is a genetic factor closely related to the late onset AD disease, and constitutes a strong independent risk factor for sporadic $\mathrm{AD} .{ }^{2}$ However, the $A P O E$ gene explains only a fraction of the 
genetic risk associated with $\mathrm{AD}$, and it is possible that other genes or metabolic factors may modify the $A P O E$ effect to initiate the pathogenesis of $\mathrm{AD}$.

In the past, genetic research had focused on identifying common population polymorphism loci, such as $A P O E$, as well as other genes such as CLU, CR1, PICALM and EXOC3L2, which have been associated with an increased risk for developing $\mathrm{AD} .^{3-6}$ These genes are implicated in chaperone action, positive regulation immune response and regulation of receptor-mediated endocytosis. Strikingly, although these genes have a significant effect on the risk of $\mathrm{AD}$, risks differ by more than two orders of magnitude lower than APOE.

Oestrogens are pleiotropic hormones having an influence not only on the reproductive system but also on the central nervous system (CNS). These hormones are synthesised by ovaries and are also produced in smaller amounts by other tissues such as glia in CNS, having a wide spectrum of neuroprotective and antiapoptotic effects. $^{7-9}$ Synaptogenic effects of estradiol-17- $\beta$ have been demonstrated in the adult mammalian brain (rodent and monkey models); low levels of estradiol are correlated with lower synapse density, while high estradiol levels are correlated with a higher density of synapses in the hippocampal region and dendritic spine density in CA1 pyramidal cells. ${ }^{10}{ }^{11}$ Among the other positive effects of oestrogens, ${ }^{12}$ estradiol-17- $\beta$ has an effect on (1) the maintenance and increase of the neurotransmitter systems, (2) the APP processing, $A \beta$ levels and factors that alter its clearance and aggregation ${ }^{13}$ and (3) mechanisms of oxidative damage. Multiple lines of evidence suggest that loss of oestrogens in the ageing brain of women and men may play a role in the cognitive declines associated with $\mathrm{AD},{ }^{14}$ but whether the female sex is also a risk factor is controversial, although some past studies and a recent study show higher rates of cognitive decline for women and apolipoprotein E4 carriers (APOE* $\left.{ }^{*} 4\right),{ }^{15} 16$ and mouse AD-transgenic mice studies generally show great amyloid and neurodegeneration in females. ${ }^{17} 18$ However, despite the initial data, ${ }^{19-22}$ there is disagreement regarding hormonal replacement therapy in women. ${ }^{14} 23-25$

Furthermore, it has also described an interaction with ApoE. Estradiol increased ApoE levels and neurite outgrowth. The APOE* $\varepsilon 2$ isoform increased the neurite length more than did the $\mathrm{APOE}^{*} \varepsilon 3$ isoform in the presence of estradiol-17- $\beta$. The hormone had no effect on neurite outgrowth from mice lacking the $A P O E$ gene or when only $\mathrm{APOE}^{*} \varepsilon 4$, the isoform that is associated with increased risk of neurological disease, was exogenously supplied. ${ }^{26}$ These data support the hypothesis that the $A P O E$ gene plays an integral role in the neurotrophic effects of estradiol-17- $\beta$ and in the presence of a probable synergism between the ApoE subtype expression and the effects of oestrogens.

The mechanism through oestrogens exerts its neuroprotective and antineurodegenerative effects in the CNS is poorly understood and is mediated by two oestrogen receptors (ER), ER $\alpha$ and ER $\beta$ (coded by the ESR1 and ESR2 genes), expressed in neurons and glia throughout the brain, especially in the hippocampus and amyg$\mathrm{dala}^{27}{ }^{28}$ regions involved in the memory and learning process. Thus, genetic variants in the ER genes have been studied in relation to $\mathrm{AD}$. There are several polymorphic loci in intron 1 of ESR 1 gen, highlighting the PvuII and XbaI locus. ${ }^{29}$ The polymorphisms of PvuII were coded as $\mathrm{P}$ or $\mathrm{p}$ and the polymorphisms of XbaI as $\mathrm{X}$ or $\mathrm{x}$, in which the capital letter signifies the absence of the restriction site and the lower case letter signifies its presence. Participants were described as $\mathrm{pp}$ or $\mathrm{xx}$ homozygotes, $\mathrm{Pp}$ or $\mathrm{Xx}$ heterozygotes or $\mathrm{PP}$ or XX homozygotes. ${ }^{30}$ The xp haplotype has a higher expression than the XP one, but with no significant differences. ${ }^{31}$ Several studies, ${ }^{32-34}$ but not all, ${ }^{31}$ have found an increased frequency of the PvuII and Xbal ESR1 polymorphisms in patients with $\mathrm{AD}$.

Another interesting SNP is rs2228480; this polymorphism is the coding synonymous variant to codon 594 (rs2228480) within the last exon of the gene ESR1 gen. This variant is thought to play a role in distinguishing between the receptor agonist or antagonists binding to the receptor molecule. ${ }^{35}$ In addition, this SNP has been associated with schizophrenia and the mechanism of this association may involve alternative gene regulation and transcript processing. ${ }^{36}$

Other studies have shown an association between several polymorphisms of the ESR2 gene and the late onset $\mathrm{AD}$, and they found that variations in this gene could modify disease susceptibility. ${ }^{37}$ The polymorphism located in the 3'UTR of the ESR2 gene, rs4986938, has been associated with the onset of Parkinson disease ${ }^{38}$ and the susceptibility for vascular dementia $(\mathrm{VaD})$ in an Israeli cohort, but not with $\mathrm{AD}^{39}$ In the study of Dresener-Pollack et $a l,{ }^{39} \mathrm{VaD}$ is differentiated from $\mathrm{AD}$ by clinical criteria, but in the absence of imaging data, the potential misclassification is high. Thus, the results should be confirmed.

Until now, no studies have been conducted in the prodromal stages of $\mathrm{AD}$ such as mild cognitive impairment of amnestic type (MCIa). Such studies could provide information about the beginning of the disease process, helping to ensure that suitable therapeutic measures would be implemented at an early stage.

According to the above, the aim of the present study was to determine whether the ESR1 and ESR2 genes are linked to the risk of MCIa; whether there is an interaction with the $A P O E$ gene; and whether such an interaction could influence the risk of $\mathrm{AD}$ and MCIa. Our hypothesis is that the association of the ESR1 and ESR2 genes with cognitive impairment may exist only in the $\mathrm{APOE}^{*} \varepsilon 4$ carriers. We have studied this association in patients with $\mathrm{AD}$ and in patients with MCIa, the latter condition possibly representing a prodrome for $\mathrm{AD}$-type dementia. ${ }^{40}$

With the purpose of examining the association of the ESR1 and ESR2 genes involved in oestrogen metabolism, as a genetic risk factor for cognitive impairment, we 
conducted a study on a sample of patients with MCIa, AD and a control group. All subjects were analysed for the ESR1 (rs9340799, rs2234693 and rs2228480) and ESR2 (rs4986938) polymorphisms and the APOE genotype.

\section{METHODS}

This study comprised 816 Caucasian participants, included in three groups: patients with MCIa $(n=204)$, patients with $\mathrm{AD}(\mathrm{n}=350)$ and healthy controls (CTL) $(n=262)$. Participants were prospectively recruited from the neurology departments of several hospitals. Participants were aged 50 years and older. For patients with $\mathrm{AD}$ and MCIa, evaluation also included routine blood tests: haematology, biochemistry, thyroidstimulating hormone, vitamin $\mathrm{B}_{12}$ levels, syphilis serology and neuroimaging test: CT scan or MRI.

The participants were evaluated using a broad battery of neuropsychological tests: Mini-Mental State Examination (MMSE), Clinical Dementia Rating scale, CERAD protocol, Stroop test, unilateral and bilateral motor praxis, 7 min test, Trail Making Test (TMT) Parts A \& B; and neuropsychiatric inventory (NPI).

Based on the results of these evaluations, the participants were classified into the following groups: patients with MCIa, patients with $\mathrm{AD}$ and healthy control subjects.

The diagnosis of patients with MCIa was based on Petersen's criteria. ${ }^{40}$ Patients had memory complaints corroborated by an informant, representing a decline from a previous level of functioning given their age and educational level. The score in the CDR scale was required to be 0.5 , and performance in relation to other cognitive functions and daily living activities was required to be normal. The diagnosis of $\mathrm{AD}$ was based on the DSM IV and NINCDS-ADRDA criteria for probable and possible AD. Patients with a total score of less than three on the CDR scale (mild to moderate dementia) were included.

Healthy control subjects were scored within the normal ranges for age and educational level in psychometric testing, with a CDR score of 0 .

The exclusion criteria included: severe comorbidities making adequate follow-up unlikely, acute psychiatric diseases, previous cerebrovascular diseases (transient ischaemic attacks, stroke or intracranial haemorrhage), other neurodegenerative diseases and the absence of a reliable informant.

A specific database was designed and declared to the Spanish Data Protection Agency. The study was approved by the Ethics Committee of Cruces Hospital (Barakaldo, Spain). All patients signed informed consent to undergo the examination. The study was conducted in accordance with the Declaration of Helsinki concerning medical research in human subjects.

\section{Genetic analysis}

On the first visit, peripheral blood samples were collected in EDTA vacuum tubes from all individuals.
Genomic DNA was extracted by proteolytic lysis from white blood cells using the standard phenol/chloroform extraction method.

The APOE gene was amplified by PCR with $112 \mathrm{~F}$ and 158R primers, under the PCR conditions described by Wilton and Lim. ${ }^{41}$ Digestion of the amplified product was carried out with Hae II and Afl III, as described by Álvarez-Álvarez et al. ${ }^{42}$

Three single nucleotide polymorphisms (SNPs) in the ESR1 gene (rs9340799, rs2234693 and rs2228480) and one SNP in the ESR2 gene (rs4986938) were evaluated. The first two SNPs in ESR1 (rs9340799 and rs2234693) are in intron 1 and are separated by only 46 base pairs. The rs9340799 polymorphism marks an $\mathrm{A} \rightarrow \mathrm{G}$ transition 351 nucleotides upstream in intron 1 (also known as c.454-351A $>G$ ). Those with the $G$ allele have an absent $\mathrm{XbaI}$ site, which has previously been called $\mathrm{X}$ in the literature, with the A allele denoted by $\mathrm{x}$. The rs2234693 polymorphism is characterised by a $\mathrm{T} \rightarrow \mathrm{C}$ transition 397 nucleotides upstream in the intron (also known as c.454-497T>C) that obliterates the PvuII restriction site. The $\mathrm{T}$ allele has previously been called the $\mathrm{p}$ allele, while the $\mathrm{C}$ allele has been called the $\mathrm{P}$ allele, denoting the absence of the PvuII restriction site. Subjects were described as XX, xx, PP, pp, homozygotes; and Xx or Pp heterozygotes.

Taqman SNP Genotyping Assays were used to analyse the polymorphism rs2228480; G>A (SNP1) of ESR1 gen and polymorphism rs4986938; G>A (SNP2) of ESR2 gen.

SNP genotypes of candidate genes (ESR1 and ESR2) and the $A P O E$ gene were analysed blinded to clinical diagnosis.

The less frequent alleles of each SNP were evaluated, such as a combined genotype (XPAA). Therefore, with the name of XPAA, we are referring to all haplotypes with at least one $\mathrm{X}$ allele (rs9340799), one $\mathrm{P}$ allele (rs2234693), one A allele (rs2228480) and one A allele (rs4986938).

\section{Statistical analyses}

Genepop V.4.0 was used to test the goodness of the fit to the Hardy-Weinberg equilibrium by means of the Guo-Thompson exact test for all three groups studied. ${ }^{43}$ The $G$ test was also used to check the differences between the demographic and clinical variables, as well as between the allele frequencies and genotype frequencies.

Statistical analysis was also performed using the SPSS package, V.15.0. A dichotomous variable was used for each polymorphism: 'yes' or 'no' for 'carrier' or 'non carrier' of the $\mathrm{APOE}^{*} \varepsilon 4$ allele and for different alleles and genotypes of the SNPs in candidate genes (ESR1 and ESR2 genes).

Several multinomial regression models were created in order to determine the independent effects of $\mathrm{X}, \mathrm{P}$ and SNP1-A alleles of ESR1 gen and SNP2-A allele of ESR2 gen in the total sample and in the absence of the APOE* $\varepsilon^{4} 4$ allele. The effect of the APOE* $\varepsilon 4$ allele in the 
total sample and in the different diagnostic groups was also calculated. Another model was created to assess the combined effect of different polymorphisms of ESR1 and ESR2 genes and the APOE* $\varepsilon 4$ allele, based on the hypothesis that the effect of oestrogens might exist only in $\mathrm{APOE}^{*} \varepsilon 4$ allele carriers.

Because age and gender could be associated with the frequency of some polymorphisms, we adjusted our analysis for these covariates in the total sample. $p$ Values of less than 0.05 were considered statistically significant.

\section{RESULTS}

We have investigated the independent and combined associations of X, P and SNP1-A alleles of ESR1 gen and SNP2-A allele of ESR2 gen and the APOE* ${ }^{*} 4$ allele by using a case-control design.

In the present study, we analysed a sample of 204 patients with MCIa, 350 patients with $\mathrm{AD}$ and 262 healthy control subjects without significant differences in terms of age $(p>0.05)$. There was, however, a significant difference in the MMSE score between groups $(p<0.05)$ (table 1$)$. Years of education were not significantly different between groups $(\mathrm{p}=0.148)$.

Table 2 shows the allele and genotype frequencies of ESR1 and ESR2 polymorphisms and the APOE gene in MCIa, AD and controls. In all studied groups, frequencies were in the Hardy-Weinberg equilibrium $(p>0.05)$.

There were no significant differences in the allele and genotype frequencies in MCIa and $\mathrm{AD}$ compared to controls for ESR1 and ESR2 gene polymorphisms, while the differences proved to be significant for the APOE gene (table 3).

In order to determine whether the less represented alleles of SNPs in candidate genes (ESR1 and ESR2 genes) were an independent risk factor for MCIa and $\mathrm{AD}$, we selected a subgroup of individuals with MCIa and $\mathrm{AD}$ and controls with the presence of at least one of these alleles. None of them had a significant effect (data not shown).

In the total sample, the $\mathrm{APOE}^{*} \varepsilon 4$ allele is a risk factor for cognitive impairment; the ORs of developing MCIa and $\mathrm{AD}$ were 2.44 (95\% CI 1.61 to $3.69, \mathrm{p}<0.001)$ and 4.23 (95\% CI 2.93 to $6.12, \mathrm{p}<0.001$ ), respectively (table 4 ). The higher risk conferred by the $\mathrm{APOE}^{*} \varepsilon 4$ allele was observed even when the samples were subgrouped by sex, but in the $\mathrm{AD}$ women the risk was higher than in men,
4.85 (95\% CI 3.04 to $7.73, \mathrm{p}<0.001)$ vs. 3.19 (95\% CI 1.73 to $5.88, \mathrm{p}<0.001)$.

Aiming to avoid the combined effect of the less represented alleles of SNPs in candidate genes and the $\mathrm{APOE}^{*} 44$ allele, we analysed the risk of MCIa and $\mathrm{AD}$ according to the presence of X, P, SNP1-A and SNP2-A alleles and the absence of one $\mathrm{APOE}^{*} \varepsilon 4$ allele. We did not find a significant effect, even when the samples were subgrouped by sex (data not shown).

We further evaluated a possible synergistic effect between the less represented alleles of SNP in candidate genes and the $\mathrm{APOE}^{*} \varepsilon 4$ allele by using a multivariate logistic regression model. To analyse this effect, we subgrouped the subjects according to the presence of $\mathrm{X}, \mathrm{P}$, SNP1-A and SNP2-A alleles and at least one APOE*\&4 allele. A slight increase in the nominal risk of MCI and $\mathrm{AD}$ was observed. The statistical analyses were also conducted according to gender (see supplementary tables S1 and S2).

In order to analyse the combined effect between oestrogen polymorphisms, we created a genetic profile with the less represented alleles of these SNPs, expressed as XPAA. We did not find a significant risk in the absence of one $\mathrm{APOE}^{*} \varepsilon 4$ allele, but analysing the combined effect of XPAA with the APOE* $* 4$ allele, ORs were the following: MCIa, OR=3.30 (95\% CI 1.28 to $8.54, \mathrm{p}=0.014)$ and $\mathrm{AD}, \mathrm{OR}=5.16(95 \%$ CI 2.19 to $12.14, \mathrm{p}<0.001)$; these ORs were even greater than the independent effect of the $\mathrm{APOE}^{*} \varepsilon 4$ allele with $\mathrm{XPAA}(-)$ (absence of this genetic profile). Although it was expected to obtain a greater effect in men with MCI and women with $\mathrm{AD}$, according to the results shown in table 3 , when the samples were subgrouped by sex taking into account the genetic profile, women with MCIa and AD showed an increased OR, 3.84 (95\% CI 1.09 to $13.57, \mathrm{p}<0.036)$ and 8.04 (95\% CI 2.60 to $24.80, \mathrm{p}<0.001)$, respectively, compared to men (table 4).

\section{DISCUSSION}

Our study shows that neither alleles nor genotypes of SNPs rs9340799 (A>G; XbaI), rs2234693 (PvuII; C >T) and rs2228480 $(\mathrm{A}>\mathrm{G})($ ESR1 gene) and SNP rs4986938 $(\mathrm{A}>\mathrm{G})(E S R 2$ gene $)$ are independently associated with the risk of MCIa or AD. The less represented alleles of SNPs in candidate genes (ESR1 and ESR2 genes) were not an independent risk factor for MCIa and AD in the

\begin{tabular}{cllccc}
\multicolumn{2}{l}{ Table 1 } & Baseline demographic \\
\hline Group & $\mathbf{n}$ & Age $^{*}$ & Women $(\%) \dagger$ & MMSE $\ddagger$ & Education \\
\hline MCla & 204 & $70.25 \pm 8.6$ & 61.3 & $26.38 \pm 2.05$ & $8.08 \pm 4.36$ \\
AD & 350 & $72.17 \pm 8.3$ & 71.1 & $19.68 \pm 4.60$ & $8.41 \pm 7.90$ \\
CONTROLS & 262 & $74.00 \pm 9.6$ & 59.5 & $28.45 \pm 1.63$ & $9.51 \pm 4.80$ \\
\hline
\end{tabular}

*Years, mean \pm SD.

†Per cent of women in group.

†MMSE score, mean \pm SD.

$\S$ Years of education. 
Table 2 Allelic and genotypic frequency

\begin{tabular}{|c|c|c|c|}
\hline \multicolumn{4}{|l|}{ ESR1 } \\
\hline Xbal & $\begin{array}{l}\text { MCla } \\
(\mathrm{N}=204)\end{array}$ & $\begin{array}{l}\text { AD } \\
(\mathrm{N}=350)\end{array}$ & $\begin{array}{l}\text { CONTROLS } \\
(\mathrm{N}=262)\end{array}$ \\
\hline \multicolumn{4}{|l|}{ Allele } \\
\hline$x$ & 0.426 & 0.409 & 0.395 \\
\hline$x$ & 0.574 & 0.591 & 0.605 \\
\hline \multicolumn{4}{|l|}{ Genotype } \\
\hline$X X$ & 0.157 & 0.154 & 0.156 \\
\hline$X x$ & 0.539 & 0.509 & 0.477 \\
\hline$x x$ & 0.304 & 0.337 & 0.366 \\
\hline \multicolumn{4}{|l|}{$\mathrm{H}-\mathrm{W}^{*}$} \\
\hline \multicolumn{3}{|l|}{ Pvull } & 1.000 \\
\hline \multicolumn{4}{|l|}{ Allele } \\
\hline$P$ & 0.488 & 0.480 & 0.462 \\
\hline$p$ & 0.512 & 0.520 & 0.538 \\
\hline \multicolumn{4}{|l|}{ Genotype } \\
\hline PP & 0.225 & 0.209 & 0.214 \\
\hline $\mathrm{Pp}$ & 0.525 & 0.543 & 0.496 \\
\hline $\mathrm{pp}$ & 0.250 & 0.249 & 0.290 \\
\hline \multicolumn{4}{|l|}{$\mathrm{H}-\mathrm{W}^{*}$} \\
\hline \multicolumn{4}{|l|}{ SNP1 } \\
\hline \multicolumn{4}{|l|}{ Allele } \\
\hline A & 0.191 & 0.189 & 0.174 \\
\hline $\mathrm{G}$ & 0.809 & 0.811 & 0.826 \\
\hline \multicolumn{4}{|l|}{ Genotype } \\
\hline AA & 0.039 & 0.037 & 0.030 \\
\hline$A G$ & 0.304 & 0.303 & 0.286 \\
\hline GG & 0.657 & 0.660 & 0.684 \\
\hline \multicolumn{4}{|l|}{$H-W^{*}$} \\
\hline p Value & 0.818 & 0.861 & 1.000 \\
\hline \multicolumn{4}{|l|}{ ESR2 } \\
\hline \multicolumn{4}{|l|}{ SNP2 } \\
\hline \multicolumn{4}{|l|}{ Allele } \\
\hline A & 0.424 & 0.419 & 0.378 \\
\hline $\mathrm{G}$ & 0.576 & 0.581 & 0.622 \\
\hline \multicolumn{4}{|l|}{ Genotype } \\
\hline$A A$ & 0.201 & 0.189 & 0.133 \\
\hline$A G$ & 0.446 & 0.460 & 0.489 \\
\hline GG & 0.353 & 0.351 & 0.378 \\
\hline \multicolumn{4}{|l|}{$\mathrm{H}-\mathrm{W}^{*}$} \\
\hline$p$ Value & 0.245 & 0.325 & 0.591 \\
\hline \multicolumn{4}{|l|}{$A P O E$} \\
\hline \multicolumn{4}{|l|}{ Allele } \\
\hline 2 & 0.027 & 0.034 & 0.057 \\
\hline 3 & 0.743 & 0.665 & 0.842 \\
\hline 4 & 0.230 & 0.301 & 0.101 \\
\hline Genotype & & & \\
\hline 2,2 & 0.000 & 0.000 & 0.008 \\
\hline 2,3 & 0.044 & 0.046 & 0.092 \\
\hline 2,4 & 0.010 & 0.017 & 0.008 \\
\hline 3,3 & 0.574 & 0.434 & 0.698 \\
\hline 3,4 & 0.294 & 0.420 & 0.195 \\
\hline 4,4 & 0.078 & 0.083 & 0.000 \\
\hline $\mathrm{H}-\mathrm{W}^{*}$ & & & \\
\hline $\begin{array}{c}p \text { Value } \\
\text { Genetic pro }\end{array}$ & 0.217 & 0.814 & 0.102 \\
\hline XPAA(+) & 0.709 & 0.708 & 0.674 \\
\hline XРAA(-) & 0.291 & 0.292 & 0.326 \\
\hline
\end{tabular}

absence of $\mathrm{APOE}^{*} \varepsilon 4$. Furthermore, the genetic profile created with the less represented alleles of SNPs in candidate genes were associated with an increased risk for MCIa and AD in women and APOE*\&4 allele carriers.

In our series, the APOE* $\varepsilon 4$ allele seems to be an independent risk factor for the population with $\mathrm{AD}$, and this risk is highest for women. The APOE*\&4 allele also constitutes a risk factor for patients with MCIa.

On evaluating the combined effect of the $\mathrm{APOE}^{*} \varepsilon 4$ allele in the presence of alleles or genotypes of ESRI and ESR2 SNPs the risk for AD remains significant, although this association did not confer a relevant additional risk of MCIa and $\mathrm{AD}$.

When we created a genetic profile with the less represented alleles of ESR1 and ESR2 SNPs, expressed as XPAA, we did not find a significant risk in the absence of one $\mathrm{APOE}^{*} \varepsilon 4$ allele. However, the presence of XPAA and at least one $\mathrm{APOE}^{*} \varepsilon 4$ allele increases the risk in women with MCIa and AD.

Nowadays, the most well-known polymorphism of the ESR1 gene related to AD are SNPs rs9340799 (A>G; XbaI) and rs2234693 (PvuII; T>C). As regards the association between $\mathrm{XbaI}$ with $\mathrm{AD}$, several studies show that the ESR1 XbaI polymorphism is an additional risk factor. ${ }^{32}{ }^{44-46}$ However, other studies have not found this association. ${ }^{34}{ }^{47-50}$ These results and several meta-analyses $^{51}$ suggested that the ESR1 gene polymorphisms might be related to the individual susceptibility to $\mathrm{AD}$, especially in women.

Several published studies have shown a great heterogeneity concerning the association between the ESRI PvuII polymorphism and AD. In some of them, no association has been found. ${ }^{31} 47 \quad 4850 \quad 52$ Some studies claimed a protective role for the $\mathrm{P}$ allele of the ESRI PvuII polymorphism, ${ }^{34} 4546$ whereas others found an opposite effect. ${ }^{32} 33{ }^{44}{ }^{53-55}$ Some studies ${ }^{44}$ have established an association between ESR1 PP and XX genotypes with an increased risk for $\mathrm{AD}$ only in men (OR=3.6, 95\% CI 1.2 to 10.9 ) and conferred a relevant additional risk of $\mathrm{AD}$ on subjects also carrying the $\mathrm{APOE}^{*} \varepsilon 4$ allele and in women with $\mathrm{AD}$. In this last study, the ESR1 PP and XX genotypes were also associated with lower MMSE values $(\mathrm{p}=0.0007)$. These data suggest that the involvement of ESR1 polymorphisms (XbaI and PvuII) in $\mathrm{AD}$ onset is mediated by the regulation of $A P O E$ expression. Our data support this hypothesis, in accordance with the increased risk of MCI and $\mathrm{AD}$ observed in patients with the $\mathrm{APOE}^{*} \varepsilon 4$ allele.

To our knowledge, this is the first study to show evidence in support of the association of SNP rs2228480 with patients with $\mathrm{MCI}$ and $\mathrm{AD}$ and the $\mathrm{APOE}^{*} 4$ allele carriers. Previously, this SNP had only been linked to the alternative regulation and transcript processing of the ESR1 gene. ${ }^{36} 56$ Until now additional information has not been provided with regard to neurodegenerative disorders.

Regarding polymorphisms of the ESR2 gen, several studies have been published with conflicting results: susceptibility for $\mathrm{VaD}$ but not for sporadic $\mathrm{AD}$ in elderly 
Table 3 Exact $\mathrm{G}$ test

\begin{tabular}{|c|c|c|c|c|c|}
\hline & $p$ Value & SE & & $p$ Value & SE \\
\hline$\overline{\mathbf{X b a l}^{*}}$ & & & Xbal† & & \\
\hline $\mathrm{MCl}$ vs CTL & 0.339 & 0.006 & $\mathrm{MCl}$ vs CTL & 0.336 & 0.004 \\
\hline $\mathrm{MCl}$ vs $A D$ & 0.571 & 0.005 & $\mathrm{MCl}$ vs $A D$ & 0.564 & 0.004 \\
\hline$A D$ vs $C T L$ & 0.638 & 0.005 & $A D$ vs $C T L$ & 0.635 & 0.004 \\
\hline$\overline{\text { Pvull }^{*}}$ & & & Pvull† & & \\
\hline$\overline{\mathrm{MCl}}$ vs CTL & 0.479 & 0.006 & $\mathrm{MCl}$ vs CTL & 0.464 & 0.004 \\
\hline $\mathrm{MCl}$ vs $A D$ & 0.853 & 0.002 & $\mathrm{MCl}$ vs $A D$ & 0.846 & 0.002 \\
\hline$A D$ vs $C T L$ & 0.562 & 0.006 & $A D$ vs $C T L$ & 0.548 & 0.005 \\
\hline SNP1* & & & SNP1† & & \\
\hline$\overline{\mathrm{MCl} \text { vs CTL }}$ & 0.483 & 0.005 & $\mathrm{MCl}$ vs $\mathrm{CTL}$ & 0.491 & 0.004 \\
\hline $\mathrm{MCl}$ vs $A D$ & 0.935 & 0.002 & $\mathrm{MCl}$ vs $A D$ & 0.935 & 0.001 \\
\hline$A D$ vs $C T L$ & 0.532 & 0.011 & $A D$ vs $C T L$ & 0.552 & 0.007 \\
\hline SNP2* & & & SNP2† & & \\
\hline$\overline{\mathrm{MCl} \text { vs CTL }}$ & 0.180 & 0.009 & $\mathrm{MCl}$ vs CTL & 0.153 & 0.005 \\
\hline $\mathrm{MCl}$ vs $A D$ & 0.896 & 0.003 & $\mathrm{MCl}$ vs $A D$ & 0.904 & 0.003 \\
\hline$A D$ vs $C T L$ & 0.139 & 0.007 & $A D$ vs $C T L$ & 0.173 & 0.009 \\
\hline$\overline{A P O E^{*}}$ & & & APOE† & & \\
\hline$\overline{\mathrm{MCl}}$ vs CTL & 0.000 & $<0.001$ & $\mathrm{MCl}$ vs CTL & 0.000 & $<0.001$ \\
\hline $\mathrm{MCl}$ vs $A D$ & 0.033 & 0.002 & $\mathrm{MCl}$ vs $A D$ & 0.033 & 0.002 \\
\hline$A D$ vs $C T L$ & 0.000 & $<0.001$ & $A D$ vs $C T L$ & 0.000 & $<0.001$ \\
\hline
\end{tabular}

${ }^{*}$ Allelic frequency.

†Genotypic frequency.

Jewish women was found in the ESR2 rs4986938 polymorphism. ${ }^{39}$ Pirskanen $e t a \hat{l}^{77}$ found that some gene variants of the ESR2 gen are associated with increased risk of $\mathrm{AD}$ in women $(\mathrm{rs} 1271573 \mathrm{~T} / \mathrm{T}$ genotype and rs1256043 $\mathrm{T} / \mathrm{T}$ genotype) while others are not (IVS31842, rs4986938). Lambert et at $t^{48}$ found no independent association of these polymorphisms with the risk of developing $\mathrm{AD}$. One study suggests that the ESR2 allele 5 seems to be a protective factor. ${ }^{57}$ Meta-analyses have not been performed on the following polymorphisms of the ESR2 gen since they lack published genotype data or the published genotype data were not eligible for inclusion. Other studies ${ }^{58}$ have not detected a significant gene-gene interaction between ESR1, ESR2 SNPs and $A P O E$ status, but the analysis was performed in late onset $\mathrm{AD}$.

In contrast with previous studies, we have analysed the genetic profile of the less represented alleles of the ESR1 and ESR2 gene polymorphisms, XPAA; when considering the XPAA isolatedly, the genetic profile was not an independent risk factor for MCIa and $\mathrm{AD}$, but the combined effect with the $\mathrm{APOE}^{*} \varepsilon 4$ allele confers an increased risk in women, while it does not contribute to the disease susceptibility in men. Analysis of haplotypes offers more power to detect associations than does simply focusing on a single variant, but in our case the actual results differed slightly from those expected. The combined effect observed between X, P, SNP1-A and SNP2-A alleles and at least one APOE* ${ }^{2} 4$ allele seemed to point to an increased risk in men with MCIa and women with $\mathrm{AD}$. Our case-control study is relatively medium sized with a small number of samples carrying the genetic profile $(<8 \%$ in patients with $\mathrm{MCI}$ and $\mathrm{AD}$ and $<2 \%$ in controls) and the APOE* ${ }^{*} 4$ allele that may affect the power negatively. Nevertheless, according to our results, some variations in the ER genes in synergy with the $\operatorname{APOE}^{*} \varepsilon 4$ allele may be associated with an increased risk of MCIa and AD in women.

Our results may suggest that the risk for MCIa and $\mathrm{AD}$ may be modulated only when the ESR1 and ESR2 genes have several polymorphisms, which might be related to their expression and biological activities. The variations in the ER genes may involve alternative gene regulation and transcript processing in the brain. ${ }^{36}$ The APOE gene expression can be differentially regulated depending on the activation of ER subtypes. A recent study ${ }^{59}$ demonstrated that activation of the ESR1 gene upregulated the APOE* ${ }^{*} 4$ mRNA and protein expression in the hippocampus. In contrast, an activation of the ESR2 gene downregulated the mRNA and protein expression of the $A P O E$ gene. Thus, it is expected to lower regulation in postmenopausal women ${ }^{60}$ conferring less protection against the effect of the $\mathrm{APOE}^{*} \varepsilon 4$ allele.

Relatively few studies have examined the epistatic effects between the oestrogen-related pathway genes and the $\mathrm{APOE}^{*} \varepsilon 4$ allele. Postmenopausal women with Down syndrome showed an increased risk of $\mathrm{AD}$ and an elevated sex hormone binding globulin in those carrying CYP17 and CYP19 variants and the $\mathrm{APOE}^{*} \varepsilon 4$ allele. ${ }^{61}$ Both genes are involved in the production of neurosteroids (oestrogens and testosterone). In addition, oestrogens have been shown to affect amyloid precursor 
Table 4 Risk Factors for MCl and AD from Logistic Regression Models

\begin{tabular}{|c|c|c|c|c|}
\hline & \multicolumn{2}{|l|}{$\mathrm{MCl}$} & \multicolumn{2}{|l|}{ AD } \\
\hline & OR Cl 95\% & p Value & OR CI 95\% & p Value \\
\hline \multicolumn{5}{|l|}{ Global effects } \\
\hline$x(+) \dagger$ & 1.39 (0.93 to 2.06$)$ & 0.104 & 1.18 (0.85 to 1.67$)$ & 0.324 \\
\hline$P(+) \ddagger$ & $1.25(0.82$ to 1.90$)$ & 0.293 & $1.26(0.88$ to 1.23$)$ & 0.205 \\
\hline SNP1-A§ & $1.14(0.76$ to 1.71$)$ & 0.506 & $1.13(0.78$ to 1.62$)$ & 0.510 \\
\hline SNP2-Aף & $1.05(0.71$ to 1.54$)$ & 0.304 & $1.08(0.77$ to 1.51$)$ & 0.649 \\
\hline $\mathrm{E} 4(+)^{\star \star}$ & 2.44 (1.61 to 3.69$)$ & $<0.001$ & 4.23 (2.93 to 6.12$)$ & $<0.001$ \\
\hline Women & $1.07(0.73$ to 1.56$)$ & 0.705 & 1.67 (1.19 to 2.35$)$ & 0.003 \\
\hline E4 (+)*Woment† & 2.27 (1.32 to 3.87$)$ & 0.003 & 4.85 (3.04 to 7.73$)$ & $<0.001$ \\
\hline E4 $(+)^{\star}$ Men $\ddagger$ & 2.74 (1.43 to 5.23$)$ & 0.002 & 3.19 (1.73 to 5.88$)$ & $<0.001$ \\
\hline \multicolumn{5}{|l|}{ Independent effects } \\
\hline$X(+)$ E4(-)§§ & $1.04(0.65$ to 1.66$)$ & 0.863 & $1.18(0.76$ to 1.81$)$ & 0.452 \\
\hline$P(+)$ E4(-)§§ & $0.86(0.52$ to 1.40$)$ & 0.545 & $1.19(0.754$ to 1.90$)$ & 0.444 \\
\hline SNP1-A $(+)^{\star} E 4(-) \S \S$ & $1.19(0.74$ to 1.92$)$ & 0.469 & $1.13(0.73$ to 1.76$)$ & 0.568 \\
\hline SNP2-A $(+)^{\star} E 4(-) \S \S$ & $1.03(0.65$ to 1.66$)$ & 0.879 & $1.07(0.70$ to 1.64 & 0.758 \\
\hline \multicolumn{5}{|l|}{ ESR1 } \\
\hline \multicolumn{5}{|l|}{ Combined effects } \\
\hline E4(+)*Xๆी & 3.17 (1.80 to 5.59$)$ & $<0.001$ & 5.07 (3.00 to 8.55$)$ & $<0.001$ \\
\hline$E 4(+)^{\star} P q \rrbracket$ & 2.74 (1.55 to 4.85$)$ & 0.001 & 5.35 (3.11 to 9.17$)$ & $<0.001$ \\
\hline E4(+)*SNP1-AףП & 2.53 (1.31 to 4.90$)$ & $<0.001$ & 4.44 (2.48 to 7.93$)$ & $<0.001$ \\
\hline \multicolumn{5}{|l|}{ ESR2 } \\
\hline \multicolumn{5}{|l|}{ Combined effects } \\
\hline E4(+) ${ }^{\star}$ SNP2-A & 2.77 (1.55 to 4.93$)$ & 0.001 & 4.87 (2.91 to 8.17$)$ & $<0.001$ \\
\hline Genetic profile (XPAA) & & & & \\
\hline \multicolumn{5}{|l|}{ Independent effects } \\
\hline $\mathrm{XPAA}^{\star} \mathrm{E} 4(-)^{\star \star \star}$ & $1.31(0.48$ to 3.54$)$ & 0.590 & $1.19(0.49$ to 2.91$)$ & 0.696 \\
\hline XPAA $(-)^{\star} \mathrm{E} 4(+) \dagger \dagger \dagger$ & $2.53(1.61$ to 3.93$)$ & $<0.001$ & 4.32 (2.91 to 6.40$)$ & $<0.001$ \\
\hline \multicolumn{5}{|l|}{ Combined effects } \\
\hline XPAA*E4(+)§§§ & 3.30 (1.28 to 8.54$)$ & 0.014 & $5.16(2.19$ to 12.14$)$ & $<0.001$ \\
\hline XPAA*E4(+)*Women§§§ & 3.84 (1.09 to 13.57$)$ & 0.036 & 8.04 (2.60 to 24.80$)$ & $<0.001$ \\
\hline $\mathrm{XPAA}^{*} \mathrm{E} 4(+)^{\star}$ Men§§§ & $3.20(0.73$ to 14.11$)$ & 0.124 & 3.57 (0.88 to 14.47$)$ & 0.075 \\
\hline
\end{tabular}

$\dagger$ Effect of sample with at least one $X$ of RFLP Xbal.

‡Effect of sample with at least one P of RFLP Pvull.

§Effect of sample with at least one A allele of rs2228480.

TEffect of sample with at least one A allele of rs4986938.

${ }^{\star *}$ Effect of sample with at least one E4 allele of the APOE gene.

††Women selected by at least one $\mathrm{E} 4$ allele of the $A P O E$ gene.

$\ddagger \ddagger$ Men selected by at least one E4 allele of the APOE gene.

$\S \S S a m p l e ~ s e l e c t e d$ by at least one allele that is indicated and the absence of the E4 allele of the APOE gene.

ๆๆ|Sample selected by at least one E4 allele of the APOE gene and one of the alleles that is indicated. The reference category was sample control.

*** Sample selected by absence of the E4 allele of the APOE gene and the presence of XPAA.

t†† Sample selected by absence of XPAA and the presence by at least one E4 allele of the APOE gene. Sample selected by at least one E4 allele of the APOE gene and the presence XPAA.

$\$ \ddagger \ddagger$ Sample selected by at least one E4 allele of the APOE gene and the presence of XPAA.

$\S \S \S$ Women or men selected by at least one E4 allele of the APOE gene and the presence of XPAA. * In all models, the reference category was sample control considering the age and sex (as appropriate).

protein metabolism, by increasing the secretory metabolism of amyloid protein precursor (App). Oestrogens are also a potent factor that not only prevents vascular disease but also improves blood flow, including blood flow in regions of the brain affected by $\mathrm{AD} .{ }^{62}$ Synaptic sprouting by estradiol in a model of $\mathrm{AD}$ may operate via an $\mathrm{APOE}^{*} \varepsilon 4$-dependent mechanism. ${ }^{63}$ Cholinergic neurons that are implicated in cognitive functions may be regulated by oestrogens. The distribution of ERs corresponds to that of the cholinergic system. ${ }^{64}$ The important decrease in endogenous oestrogen levels after menopause may contribute to the development of $\mathrm{AD} .^{65}$ Despite the protective effect of oestrogens on $\mathrm{AD}$, this effect might be modified by ER polymorphisms, particularly in the $\operatorname{APOE}^{*} \varepsilon 4$ allele carriers. Thus, the current state of knowledge of the role of oestrogens in preventing dementia in postmenopausal women should be reviewed.

Although the prevalence and incidence of $\mathrm{AD}$ are higher in women, men may also have the same effect due to SNPs in ER genes. It has been observed that while androgens have specific receptors to exert their neuroprotective action, they may also exert their actions 
indirectly via $C Y P 17$ by aromatisation of testosterone to estradiol $^{66}$ or directly through the binding of the metabolite dihydrotestosterone to ESR2. ${ }^{67}$ Until now, it is unclear whether SNPs in ER genes would increase the risk of $\mathrm{AD}$ or MCIa in men. Our partial data show a tendency to increase the risk of MCIa in men. Future studies should elucidate whether there is a relationship between ER genes and MCIa in men.

The strengths of our study are its multicenter nature including patients with $\mathrm{AD}$, healthy controls and patients with MCIa. To our knowledge, our study is the first to investigate an association between polymorphisms of ER (rs9340799, rs2234693, rs2228480 and rs4986938) and cognitive function not only in patients with $\mathrm{AD}$, but also in patients with MCIa. Moreover, the patient sample is not small, allowing gender stratification.

Some limitations in our study must be addressed. The study population comes from the hospital setting. A community-based study could provide more information. The serum levels of estradiol have not been measured, and we do not know whether the patients received ERT in the last years. We also include a sample of patients with MCIa; this stage is probably a heterogeneous clinical entity, but the broad battery of neuropsychological tests used in our sample might ensure the highest homogeneity.

\section{CONCLUSIONS}

In our study, the $\mathrm{APOE}^{*} \varepsilon 4$ allele is an independent risk factor for patients with MCIa and AD. The combined effect of the $\mathrm{APOE}^{*} \varepsilon 4$ allele and the less represented alleles of ESR1 and ESR2 SNPs remains the risk for MCIa and $\mathrm{AD}$; this association confers a relevant additional risk of $\mathrm{AD}$ and MCIa in women and men, respectively. Nevertheless, the genetic profile with the less represented alleles of the ESR1 and ESR2 gene polymorphisms, expressed as XPAA, did not increase the risk of cognitive impairment in the absence of one $\mathrm{APOE}^{*} \varepsilon 4$ allele, but the presence of XPAA and at least one $\mathrm{APOE}^{*} \varepsilon 4$ allele only increases the risk in women with MCIa and AD.

\footnotetext{
Author affiliations

${ }^{1}$ Department of Neurology, Hospital Universitario Cruces, BioCruces Health Research Institute, Barakaldo, Bizkaia, Spain

${ }^{2}$ BIOMICS Research Group, Department of Z and Cellular Biology A, Centro de Investigación y Estudios Avanzados Lucio Lascaray (CIEA). University of Basque Country UPV/EHU, Vitoria-Gasteiz, Álava, Spain

${ }^{3}$ Department of Neurology, Hospital Universitario Txagorritxu, Vitoria-Gazteiz, Álava, Spain

${ }^{4}$ San Prudencio Comprehensive Care Center for Elderly, Vitoria-Gasteiz City Council Basque Country, Vitoria-Gasteiz, Álava, Spain

${ }^{5}$ Department of Neurology, Hospital Universitario Basurto, Bilbao, Vizcaya, Spain

${ }^{6}$ Department of Neurology, Hospital Universitario Donostia, Donostia, Guipuzcoa, Spain

${ }^{7}$ Department of Neurology, Hospital de Galdakao, Galdakao, Vizcaya, Spain ${ }^{8}$ Department of Neurology, Hospital Santiago Apóstol, Vitoria-Gazteiz, Vizcaya, Spain
}

Contributors MFM conceived the study and participated in its design and coordination, as well as drafting the manuscript. XEM participated in the study design and coordination and helped to draft the manuscript, EBM, IUS and MAA were involved in the drafting of the manuscript. LGA and FGB were involved in the study design and coordination and helped to draft the manuscript. AMS, RGB, SIB, NO, MBA and MCZ performed the battery of neuropsychological tests. JMUV, BIJ, MAGB and JML participated in the design of the study and coordination of the manuscript. MMP participated in the study design and coordination and helped to draft the manuscript. All authors read and approved the final manuscript.

Funding This work was sponsored by grants from the Federación de Asociaciones de Familiares de enfermos de Alzheimer de Euskadi, Fondo de Investigación Sanitaria del Instituto Carlos III (Madrid), Pfizer Foundation and Ayudas a la Investigación de la Obra Social de la Caja Vital Kutxa.

Competing interests None.

Patient consent Obtained.

Ethics approval Approved by the Ethics Committee of Cruces Hospital (Barakaldo, Spain)

Provenance and peer review Not commissioned; externally peer reviewed.

Data sharing statement No additional data are available.

Open Access This is an Open Access article distributed in accordance with the Creative Commons Attribution Non Commercial (CC BY-NC 3.0) license, which permits others to distribute, remix, adapt, build upon this work noncommercially, and license their derivative works on different terms, provided the original work is properly cited and the use is non-commercial. See: http:// creativecommons.org/licenses/by-nc/3.0/

\section{REFERENCES}

1. Bertram L, McQueen MB, Mullin K, et al. Systematic meta-analyses of Alzheimer disease genetic association studies: the AlzGene database. Nat Genet 2007;39:17-23.

2. Saunders AM, Strittmatter WJ, Schmechel D, et al. Association of apolipoprotein $\mathrm{E}$ allele epsilon 4 with late-onset familial and sporadic Alzheimer's disease. Neurology 1993;43:1467-72.

3. Carrasquillo MM, Belbin O, Hunter TA, et al. Replication of CLU, CR1, and PICALM associations with alzheimer disease. Arch Neurol 67:961-4.

4. Harold D, Abraham R, Hollingworth $P$, et al. Genome-wide association study identifies variants at CLU and PICALM associated with Alzheimer's disease. Nat Genet 2009;41:1088-93.

5. Lambert JC, Heath S, Even G, et al. Genome-wide association study identifies variants at CLU and CR1 associated with Alzheimer's disease. Nat Genet 2009;41:1094-9.

6. Seshadri S, Fitzpatrick AL, Ikram MA, et al. Genome-wide analysis of genetic loci associated with Alzheimer disease. JAMA 2010;303:1832-40.

7. Garcia-Segura LM, McCarthy MM. Minireview: role of glia in neuroendocrine function. Endocrinology 2004;145:1082-6.

8. Hu R, Cai WQ, Wu XG, et al. Astrocyte-derived estrogen enhances synapse formation and synaptic transmission between cultured neonatal rat cortical neurons. Neuroscience 2007;144:1229-40.

9. Marin R, Guerra B, Alonso R, et al. Estrogen activates classical and alternative mechanisms to orchestrate neuroprotection. Curr Neurovasc Res 2005;2:287-301.

10. Hao J, Janssen WG, Tang $Y$, et al. Estrogen increases the number of spinophilin-immunoreactive spines in the hippocampus of young and aged female rhesus monkeys. J Comp Neurol 2003;465:540-50.

11. Woolley CS, McEwen BS. Estradiol mediates fluctuation in hippocampal synapse density during the estrous cycle in the adult rat. J Neurosci 1992;12:2549-54.

12. Pike CJ, Carroll JC, Rosario ER, et al. Protective actions of sex steroid hormones in Alzheimer's disease. Front Neuroendocrinol 2009;30:239-58.

13. Amtul Z, Wang L, Westaway D, et al. Neuroprotective mechanism conferred by 17beta-estradiol on the biochemical basis of Alzheimer's disease. Neuroscience 169(2):781-6.

14. Janicki SC, Schupf N. Hormonal influences on cognition and risk for Alzheimer's disease. Curr Neurol Neurosci Rep 10(5):359-66.

15. Seshadri S, Fitzpatrick AL, Ikram MA, et al. Genome-wide analysis of genetic loci associated with Alzheimer disease. JAMA 303:1832-40. 
16. Holland D, Desikan RS, Dale AM, et al. Higher Rates of Decline for Women and Apolipoprotein E \&4 Carriers. AJNR Am J Neuroradio. 2013 Jul 4. [Epub ahead of print]. doi: 10.3174/ajnr.A3601

17. Callahan MJ, Lipinski WJ, Bian F, et al. Augmented senile plaque load in aged female beta-amyloid precursor protein-transgenic mice. Am J Pathol 2001;158:1173-7.

18. Wang J, Tanila H, Puolivali J, et al. Gender differences in the amount and deposition of amyloidbeta in APPswe and PS1 double transgenic mice. Neurobiol Dis 2003;14:318-27.

19. Baldereschi M, Di Carlo A, Lepore V, et al. Estrogen-replacement therapy and Alzheimer's disease in the Italian Longitudinal Study on Aging. Neurology 1998;50:996-1002.

20. Tang MX, Jacobs D, Stern $\mathrm{Y}$, et al. Effect of oestrogen during menopause on risk and age at onset of Alzheimer's disease. Lancet 1996;348:429-32.

21. Kawas C, Resnick S, Morrison A, et al. A prospective study of estrogen replacement therapy and the risk of developing Alzheimer's disease: the Baltimore longitudinal study of aging. Neurology 1997;48: 1517-21.

22. Resnick SM, Metter EJ, Zonderman AB. Estrogen replacement therapy and longitudinal decline in visual memory. A possible protective effect? Neurology 1997;49:1491-7.

23. Hogervorst E, Bandelow S. Brain and cognition. Is there any case for improving cognitive function in menopausal women using estrogen treatment? Minerva Ginecol 2009;61:499-515.

24. Maki PM, Sundermann E. Hormone therapy and cognitive function. Hum Reprod Update 2009;15:667-81.

25. Henderson VW. Alzheimer's disease: review of hormone therapy trials and implications for treatment and prevention after menopause. J Steroid Biochem Mol Biol. 2013 May 28. pii: S0960-0760(13) 00081-2 doi:10.1016/j.jsbmb.2013.05.010 [Epub ahead of print].

26. Nathan BP, Barsukova AG, Shen F, et al. Estrogen facilitates neurite extension via apolipoprotein $\mathrm{E}$ in cultured adult mouse cortical neurons. Endocrinology 2004;145:3065-73.

27. Shughrue $\mathrm{P}$, Scrimo $\mathrm{P}$, Lane $\mathrm{M}$, et al. The distribution of estrogen receptor-beta $\mathrm{mRNA}$ in forebrain regions of the estrogen receptor-alpha knockout mouse. Endocrinology 1997;138: 5649-52.

28. Shughrue PJ, Lane MV, Merchenthaler I. Comparative distribution of estrogen receptor-alpha and-beta mRNA in the rat central nervous system. J Comp Neurol 1997;388:507-25.

29. Castagnoli A, Maestri I, Bernardi F, et al. Pvull RFLP inside the human estrogen receptor gene. Nucleic Acids Res 1987;15:866

30. Yaffe K, Lui LY, Grady D, et al. Estrogen receptor 1 polymorphisms and risk of cognitive impairment in older women. Biol Psychiatry 2002;51:677-82.

31. Maruyama $\mathrm{H}$, Toji $\mathrm{H}$, Harrington $\mathrm{CR}$, et al. Lack of an association of estrogen receptor alpha gene polymorphisms and transcriptional activity with Alzheimer disease. Arch Neurol 2000;57:236-40.

32. Brandi ML, Becherini L, Gennari L, et al. Association of the estrogen receptor alpha gene polymorphisms with sporadic Alzheimer's disease. Biochem Biophys Res Commun 1999;265:335-8.

33. Isoe-Wada K, Maeda M, Yong J, et al. Positive association between an estrogen receptor gene polymorphism and Parkinson's disease with dementia. Eur J Neurol 1999;6:431-5.

34. Mattila KM, Axelman K, Rinne JO, et al. Interaction between estrogen receptor 1 and the epsilon4 allele of apolipoprotein $E$ increase the risk of familial Alzheimer's disease in women. Neurosci Lett 2000;282:45-8.

35. Pavao M, Traish AM. Estrogen receptor antibodies: specificity and utility in detection, localization and analyses of estrogen receptor alpha and beta. Steroids 2001;66:1-16.

36. Weickert CS, Miranda-Angulo AL, Wong J, et al. Variants in the estrogen receptor alpha gene and its mRNA contribute to risk for schizophrenia. Hum Mol Genet 2008;17:2293-309.

37. Pirskanen M, Hiltunen M, Mannermaa A, et al. Estrogen receptor beta gene variants are associated with increased risk of Alzheimer's disease in women. Eur J Hum Genet 2005;13:1000-6.

38. Westberg L, Hakansson A, Melke J, et al. Association between the estrogen receptor beta gene and age of onset of Parkinson's disease. Psychoneuroendocrinology 2004;29:993-8.

39. Dresner-Pollak R, Kinnar T, Friedlander $\mathrm{Y}$, et al. Estrogen receptor beta gene variant is associated with vascular dementia in elderly women. Genet Test Mol Biomarkers 2009;13:339-42.

40. Petersen RC. Mild cognitive impairment clinical trials. Nat Rev Drug Discov 2003;2:646-53.

41. Wilton S, Lim L. Rapid identification of ApoE alleles by multiple-single-strand conformation polymorphism (SSCP) analysis. Trends Genet 1995;11:341.

42. Alvarez-Alvarez M, Galdos L, Fernandez-Martinez M, et al. 5-Hydroxytryptamine 6 receptor $(5-\mathrm{HT}(6))$ receptor and apolipoprotein $\mathrm{E}$ (ApoE) polymorphisms in patients with Alzheimer's disease in the Basque Country. Neurosci Lett 2003;339:85-7.

43. Rousset F. genepop'007: a complete re-implementation of the genepop software for Windows and Linux. Mol Ecol Resources 2008;8:103-6.

44. Corbo RM, Gambina G, Ruggeri M, et al. Association of estrogen receptor alpha (ESR1) Pvull and Xbal polymorphisms with sporadic Alzheimer's disease and their effect on apolipoprotein $E$ concentrations. Dement Geriatr Cogn Disord 2006;22:67-72.

45. Monastero R, Cefalu AB, Camarda C, et al. Association of estrogen receptor alpha gene with Alzheimer's disease: a case-control study. J Alzheimers Dis 2006;9:273-8.

46. Porrello E, Monti MC, Sinforiani E, et al. Estrogen receptor alpha and APOEepsilon4 polymorphisms interact to increase risk for sporadic AD in Italian females. Eur J Neurol 2006;13:639-44.

47. Den Heijer T, Schuit SC, Pols HA, et al. Variations in estrogen receptor alpha gene and risk of dementia, and brain volumes on MRI. Mol Psychiatry 2004;9:1129-35.

48. Lambert JC, Harris JM, Mann D, et al. Are the estrogen receptors involved in Alzheimer's disease? Neurosci Lett 2001;306:193-7.

49. Prince JA, Feuk L, Sawyer SL, et al. Lack of replication of association findings in complex disease: an analysis of 15 polymorphisms in prior candidate genes for sporadic Alzheimer's disease. Eur J Hum Genet 2001;9:437-44.

50. Usui C, Shibata N, Ohnuma T, et al. No genetic association between the myeloperoxidase gene-463 polymorphism and estrogen receptor-alpha gene polymorphisms and Japanese sporadic Alzheimer's disease. Dement Geriatr Cogn Disord 2006;21:296-9.

51. Luckhaus C, Sand PG. Estrogen Receptor 1 gene (ESR1) variants in Alzheimer's disease. Results of a meta-analysis. Aging Clin Exp Res 2007;19:165-8.

52. Rodriguez E, Mateo I, Llorca J, et al. No association between low density lipoprotein receptor genetic variants and Alzheimer's disease risk. Am J Med Genet B Neuropsychiatr Genet 2006;141B:541-3.

53. Boada M, Antunez C, Lopez-Arrieta J, et al. Estrogen receptor alpha gene variants are associated with Alzheimer's disease. Neurobiol Aging 2012;33:198.e15-24

54. Ji Y, Urakami K, Wada-Isoe K, et al. Estrogen receptor gene polymorphisms in patients with Alzheimer's disease, vascular dementia and alcohol-associated dementia. Dement Geriatr Cogn Disord 2000;11:119-22.

55. Lin GF, Ma QW, Zhang DS, et al. Polymorphism of alpha-estrogen receptor and aryl hydrocarbon receptor genes in dementia patients in Shanghai suburb. Acta Pharmacol Sin 2003;24:651-6.

56. Long JR, Xu H, Zhao LJ, et al. The oestrogen receptor alpha gene is linked and/or associated with age of menarche in different ethnic groups. J Med Genet 2005;42:796-800.

57. Forsell $\mathrm{C}$, Enmark $\mathrm{E}$, Axelman $\mathrm{K}$, et al. Investigations of a CA repeat in the oestrogen receptor beta gene in patients with Alzheimer's disease. Eur J Hum Genet 2001;9:802-4.

58. Goumidi L, Dahlman-Wright K, Tapia-Paez I, et al. Study of estrogen receptor- $\alpha$ and receptor- $\beta$ gene polymorphisms on Alzheimer's disease. Alzheimers Dis 2011;26:431-9.

59. Wang X, Dykens JA, Perez E, et al. Neuroprotective effects of 17beta-estradiol and nonfeminizing estrogens against $\mathrm{H}_{2} \mathrm{O}_{2}$ toxicity in human neuroblastoma SK-N-SH cells. Mol Pharmacol 2006;70:395-404

60. Ishunina TA, Van Heerikhuize JJ, Ravid R, et al. Estrogen receptors and metabolic activity in the human tuberomamillary nucleus: changes in relation to sex, aging and Alzheimer's disease. Brain Res 2003;988:84-96.

61. Chace C, Pang D, Weng C, et al. Variants in CYP17 and CYP19 cytochrome P450 genes are associated with onset of Alzheimer's disease in women with down syndrome. J Alzheimers Dis 2012:28:601-12.

62. Birge SJ. The role of estrogen in the treatment of Alzheimer's disease. Neurology 1997;48(5 Suppl):S36-41.

63. Stone DJ, Rozovsky I, Morgan TE, et al. Increased synaptic sprouting in response to estrogen via an apolipoprotein E-dependent mechanism: implications for Alzheimer's disease. J Neurosci 1998;18:3180-5.

64. Toran-Allerand CD, Miranda RC, Bentham WD, et al. Estrogen receptors colocalize with low-affinity nerve growth factor receptors in cholinergic neurons of the basal forebrain. Proc Natl Acad Sci USA 1992;89:4668-72.

65. Gandy S. Estrogen and neurodegeneration. Neurochem Res 2003;28:1003-8.

66. Raber J. AR, apoE, and cognitive function. Hormones Behav 2008;53:706-15.

67. Lund TD, Hinds LR, Handa RJ. The androgen 5alphadihydrotestosterone and its metabolite 5alpha-androstan-3beta, 17betadiol inhibit the hypothalamo-pituitary-adrenal response to stress by acting through estrogen receptor beta-expressing neurons in the hypothalamus. J Neurosci 2006;26:1448-56. 